\title{
Quantifying capital goods for collection and transport of waste
}

\author{
Brogaard, Line Kai-Sørensen; Christensen, Thomas Højlund
}

Published in:

Waste Management and Research

Link to article, DOI:

$10.1177 / 0734242 X 12462279$

Publication date:

2012

Document Version

Peer reviewed version

Link back to DTU Orbit

Citation (APA):

Brogaard, L. K-S., \& Christensen, T. H. (2012). Quantifying capital goods for collection and transport of waste. Waste Management and Research, 30(12), 1243-1250. https://doi.org/10.1177/0734242X12462279

\section{General rights}

Copyright and moral rights for the publications made accessible in the public portal are retained by the authors and/or other copyright owners and it is a condition of accessing publications that users recognise and abide by the legal requirements associated with these rights.

- Users may download and print one copy of any publication from the public portal for the purpose of private study or research.

- You may not further distribute the material or use it for any profit-making activity or commercial gain

- You may freely distribute the URL identifying the publication in the public portal

If you believe that this document breaches copyright please contact us providing details, and we will remove access to the work immediately and investigate your claim. 


\title{
Quantifying capital goods for collection and transport of waste
}

\author{
Line Kai-Sørensen Brogaard ${ }^{1}$ \& Thomas Højlund Christensen ${ }^{1}$ \\ ${ }^{1}$ Department of Environmental Engineering \\ Technical University of Denmark \\ Kongens Lyngby, Denmark
}

\author{
* Corresponding author \\ Department of Environmental Engineering \\ Building 115 \\ Technical University of Denmark \\ 2800 Kongens Lyngby, Denmark \\ Phone: +4545251488 \\ Fax: +4545932850 \\ E-mail:1ksb@env.dtu.dk
}

NOTE: this is the author's version of a work that was accepted for publication in journal of Waste Management and Research. Changes resulting from the publishing process, such as peer review, editing, corrections, structural formatting, and other quality control mechanisms may not be reflected in this document. Minor changes may have been made to this manuscript since it was accepted for publication. A definitive version is published in Waste Management and Research, Vol. 30, No. 12, 2012, p. 1243-1250, doi: 10.1177/0734242X12462279 


\begin{abstract}
The capital goods for collection and transport of waste were quantified for different types of containers (plastic containers, cubes and steel containers) and an 18 tonnes compacting collection truck. The data were collected from producers and vendors of the bins and the truck. The service life time and the capacity of the goods were assessed as well. Environmental impact assessment of the production of the capital goods revealed that per tonne of waste handled, the truck had the largest contribution followed by the steel container. Large HDPE containers had the lowest impact per tonne of waste handled. The impact of producing the capital goods for waste collection and transport cannot be neglected since the capital goods dominate $(>85 \%)$ ) the categories Human-Toxicity (non cancer and cancer), Ecotoxicity, Resource Depletion and Aquatic Eutrophication, but also plays a role $(>13 \%)$ within the other impact categories when compared to the impacts from combustion of fuels for the collection and transport of the waste, when a transport distance of $25 \mathrm{~km}$ was assumed.
\end{abstract}

Keywords: Waste, environmental impact assessment, capital goods, collection, transportation. 


\section{Introduction}

Collection and transport of waste is a very important part of any waste management system: collection and transport of waste from the source to the treatment facilities, transport of recovered materials, and transport of residuals for disposal. To perform collection and transport of waste several capital goods are needed. These are among others containers for recyclables and residual municipal solid waste (MSW), containers for commercial and industrial waste, containers (cubes) for public collection points and trucks for collecting and transporting of the waste.

Rives et al. (2010) describe that studies about collection and transport of waste often focus on economics or aesthetic issues, but rarely the environmental issues are addressed. The fuel consumption of the truck in terms of emission from the combustion process is likely to be the most significant single factor as to the environmental aspects. Data on fuel consumption was reported by Larsen et al. (2009). However, the contribution of the capital goods has not been quantified and the real importance of capital goods on the environmental profile of waste collection and transport is uncertain.

Existing databases are limited on data on capital goods for waste collection and transport. An example is the data for a 21 tonnes waste collection truck which can be found in the Ecoinvent database (Ecoinvent, 2011). The data was generated by multiplying data for an average 16 tonnes truck by a factor of 1.3 to match the weight of a 21 tonnes truck. Data about containers for waste collection was not found in any available databases and the data used in this paper are collected from container producing industries.

The purpose of this paper is to quantify the capital goods for a collection and transportation system for waste. The goods in focus are four different types of containers and a medium sized collection truck for collection of MSW. These data can be used for assessing the environmental profile of a range of systems for collection and transport of waste. Such data are expected to be requested by service providers as well as by costumers in the waste collection and transport sector.

\section{Approach and method}

The four containers and the truck included in this study are presented in Table 1. The containers have been chosen to represent different volumes as well as different materials. Only one truck is included because information was difficult to retrieve. Industries and service providers were contacted in order to obtain information about volume, lifetime and capacities of the units as well as data about the material composition and specific processes involved in production and assembly of the units. The units and the sources of the data are described below.

The environmental impact assessment (EIA) model used and associated databases as well as normalization references are presented as well.

Table 1: Presentation of selected capital goods for waste collection and transport (G\&Y: Garden and yard waste. C\&D: Construction and demolition waste).

\begin{tabular}{|l|c|c|c|c|}
\hline \multirow{2}{*}{ Type } & Volume & Actual capacity & Lifetime & Waste per lifetime \\
\cline { 2 - 5 } & $\mathbf{m}^{\mathbf{3}}$ & Tonnes/year & Years & Tonnes \\
\hline 2-wheeler container & 0.24 & $1.8-2.2$ & 20 & $36-45$ \\
\hline 4-wheeler container & 1.10 & $8-10$ & 20 & $165-206$ \\
\hline Cube & 1.5 & $33-125$ & 10 & $330-1250$ \\
\hline Steel container & 19 & $44-74$ & 15 & $\begin{array}{c}\text { G\&Y waste:2223-4446 } \\
\text { C\&D waste: } 22230-29640\end{array}$ \\
\hline Collection truck & 16 & $1460-1750$ & $12-15$ & $17540-26300$ \\
\hline
\end{tabular}




\subsection{HDPE containers on wheels (2- and 4-wheeler)}

Modern waste containers typically have wheels and a grasp to match the lifting gear on the waste collection truck in order to avoid the workers carrying and lifting the container to empty it. A 2-wheeler container made of HDPE with rubber wheels and a capacity of $0.24 \mathrm{~m}^{3}$ and 4-wheeler HDPE container with metal/rubber wheels and a capacity of $1.1 \mathrm{~m}^{3}$ were considered. The data for the production of HDPE containers was obtained from the HDPE container producer Environmental Systems Expertise (ESE, 2010) - an international company with production facilities in central Europe. The containers are assumed to have a lifetime of 20 years (ESE, 2010).

The containers are considered to be used for collection of residual household waste and the bulk density of the waste in the container is assumed to be $180 \mathrm{~kg} / \mathrm{m}^{3}$ (Christensen, 2011). The filling of the HDPE containers is assumed to be $80-100 \%$. Assuming a collection frequency of once a week, the 2wheeler container is estimated to collect 36-45 tonnes during a lifetime of 20 years and the 4 -wheeler 165-206 tonnes per lifetime (Table 1).

\subsection{Cube container for public collection of recyclables}

A HDPE cube with a volume of $1.5 \mathrm{~m}^{3}$ is considered for collection of waste for recycling (e.g. paper, glass and packaging waste) at public collection points. Data concerning the cube was obtained from Kingspan - a British bin and container producer operating globally (Kingspan, 2011). The production data of the HDPE part of the container was obtained from the company Environmental Systems Expertise (ESE, 2010). The lifetime is estimated to 10 years.

The cube is considered to be used for collection of two different types of waste; paper and glass. The densities of these waste types in the cube are $420-450 \mathrm{~kg} / \mathrm{m}^{3}$ for paper and $1000-1600 \mathrm{~kg} / \mathrm{m}^{3}$ for crushed glass (Christensen, 2011). The amount of waste collected per year in the cube is estimated to 330-1250 tonnes of waste for the lifetime of the cube, assuming that the cube is emptied once a week.

\subsection{Steel container}

The steel container has a volume of $19 \mathrm{~m}^{3}$ and can be used for a range of waste types. The data for the steel container were estimated based on information provided by the vendor of the container, Lyngsgaard in Denmark (Lyngsgaard, 2011). This container consists only of steel and is painted with powder paint. A steel container may be used for heavier waste such as C\&D waste and this gives a shorter average life time than for the HDPE containers. The lifetime of the steel container is estimated to 15 years.

The steel container is assumed to be used for garden and yard (G\&Y) waste or construction and demolition (C\&D) waste. These waste types are very different with respect to bulk density. Thus, it was chosen to make the assessment for both types of waste. G\&Y waste has a density of $150-300 \mathrm{~kg} / \mathrm{m}^{3}$ (Christensen, 2011) and the density of C\&D waste is $1500-2000 \mathrm{~kg} / \mathrm{m}^{3}$ (Fatta et al., 2004). It is assumed that the $19 \mathrm{~m}^{3}$ steel container is emptied once a week. This corresponds to collection of 22204450 tonnes G\&Y waste per lifetime or 22230-29640 tonnes C\&D waste per lifetime.

\subsection{Truck}

Modern waste collection trucks are often compacting the waste in order to increase capacity and save cost. However their size and number of axles may vary depending on local factors and transport distances. For this study a medium sized rear-loading truck of 18 tonnes with two axles was evaluated.

Data concerning the 18 tonnes collection truck was obtained from Volvo (Volvo, 2010) and data for the body from the producer of bodies for collection trucks, Geesink Norba group (Geesinknorba, 2011). The truck has a self-weight of $7000 \mathrm{~kg}$ and the body for collection of waste has a self-weight of $4600 \mathrm{~kg}$. The truck has 2 axles and a capacity of around $6000 \mathrm{~kg}$ waste. It is assumed that the truck is 
collecting residual household waste once each five days a week all year corresponding to 261 loads of waste per year. The density of the waste compacted in the truck is assumed to $0.35-0.42$ tonnes $/ \mathrm{m}^{3}$ (Christensen, 2011). Considering a lifetime of 12-15 years (Dennis Eagle, 2010) the truck can collect 17540-26300 tonnes. Information about the expected lifetime of a waste collection truck was provided by the retailer of collection trucks from Dennis Eagle in Denmark (Dennis Eagle, 2010).

The size of collection trucks and thereby the number of axles needed varies depending on the use of the truck. Larger trucks have three axles whereas the one assessed in this paper is of medium size with only two axles. The difference to the 3 -axles truck is around $1300 \mathrm{~kg}$ for the chassis and $400 \mathrm{~kg}$ for the body of the waste collection truck.

\subsection{Environmental impact assessment (EIA) modelling}

The Life Cycle Assessment software Simapro 7.2 developed by Product Ecology Consultants (PRé consultants, 2011) was used for modelling the environmental impacts from the different capital goods. This software contains the necessary databases for the materials needed for the modelling and was found to be a sufficient tool for the modelling. Data concerning the materials included in the studied capital goods were found in the Swiss database Ecoinvent 2.2 (Ecoinvent, 2011). These data include material extraction, transportation of materials, and production at a plant (e.g. moulding of polyethylene).

All quantified emissions to the environment from the goods assessed were aggregated into the non toxic impact categories presented in Table 2. These categories are defined by the EDIP methodology (Wenzel et al., 1997) with the updated normalisation references from 2003 (Stranddorf et al., 2005 and Hauschild et al, 2005) also described by Laurent et al. (2011a). The normalisation references are used to present the results from the assessment in person equivalents (PE). This unit represents impacts as an average value for the total impact of the activities from a person (food, transport, housing, heating etc.) in a specific area in the reference year. The toxic impact categories are assessed by the USEtox methodology (USEtox, 2009). This methodology presents the potential impacts for human toxicity in Comparative Toxic Units (CTU) as an "estimated increase in morbidity in the total human population per unit mass of a chemical emitted (cases $/ \mathrm{kg}$ ), assuming equal weighting between cancer and non-cancer due to a lack of more precise insights into this issue" (USEtox, 2009). The potential impact on Ecotoxicity is also presented in CTU. This expresses "an estimate of the Potentially Affected Fraction of species (PAF) integrated over time and volume per unit mass of a chemical emitted (PAF m ${ }^{\mathrm{f}}$.day/kg)" (USEtox, 2009). The CTU are transformed to PE by the normalisation references presented in Table 2 . The normalisation references are provided by Laurent et al. (2011b).

For the environmental impact assessment only the productions of the capital goods are considered (see Figure 1). This study will thereby not assess the full life cycle of the goods but only assess the environmental impacts from producing the goods. The overall impacts would probably be lower if the complete life cycle was assessed including recycling of some of the materials when the goods are at end of life. 


\section{Extraction} of raw materials and production

Figure 1: Flow chart of the assessed part of life cycle for the evaluated goods. The dotted line shows the system boundary for the environmental impact assessment. All transport and energy inputs are included within the system boundary.

Table 2: Environmental impact categories and the normalisation references used for the assessment (Stranddorf et al, 2005), (Laurent et al, 2011a) and USEtox (Laurent et al, 2011b). UES: Unprotected Eco-System. CTU: Comparative Toxic Unit, e: Ecotoxicity, h: human.

\begin{tabular}{|c|c|c|c|}
\hline Impact categories & $\begin{array}{l}\text { Geographical } \\
\text { scope }\end{array}$ & $\begin{array}{l}\text { Normalization } \\
\text { references }\end{array}$ & Unit \\
\hline \multicolumn{4}{|l|}{ EDIP } \\
\hline Global warming & World & $7.73 \mathrm{E}+03$ & $\mathrm{~kg}-\mathrm{CO}_{2} \mathrm{eq} / \mathrm{person} /$ year \\
\hline Ozone depletion & World & $2.05 \mathrm{E}-02$ & kg-CFC-11 eq/person/year \\
\hline Acidification & Europe & $5.48 \mathrm{E}+01$ & $\mathrm{~kg}-\mathrm{SO}_{2} \mathrm{eq} /$ person/year \\
\hline Terrestrial eutrophication & Europe & $1.37 \mathrm{E}+03$ & $\mathrm{~m}^{2} \mathrm{UES} /$ person/year \\
\hline Aquatic eutrophication (N-equivalents) & Europe & $8.32 \mathrm{E}+00$ & kg N eq/person/year \\
\hline Aquatic eutrophication (P-equivalents) & Europe & $2.82 \mathrm{E}-01$ & $\mathrm{~kg} \mathrm{P}$ eq/person/year \\
\hline $\begin{array}{l}\text { Photochemical ozone formation - } \\
\text { impacts on vegetation }\end{array}$ & Europe & $5.97 \mathrm{E}+04$ & $\mathrm{~m}^{2} \cdot \mathrm{ppm} \cdot \mathrm{hr} /$ person/year \\
\hline $\begin{array}{l}\text { Photochemical ozone formation - } \\
\text { impacts on human health }\end{array}$ & Europe & $2.84 \mathrm{E}+00$ & $\mathrm{~m}^{2} . \mathrm{ppm} \cdot \mathrm{hr} /$ person/year \\
\hline Resource depletion & World & $8.17 \mathrm{E}-01$ & Person reserves/person/year \\
\hline \multicolumn{4}{|l|}{ USEtox } \\
\hline Human toxicity, cancer & Europe & $3.25 \mathrm{E}-05$ & CTUh/person/year \\
\hline Human toxicity, non-cancer & Europe & $8.14 \mathrm{E}-04$ & CTUh/person/year \\
\hline Ecotoxicity & Europe & $5.06 \mathrm{E}+03$ & CTUe/person/year \\
\hline
\end{tabular}

\section{Results and discussion}

The results include quantifying of the materials used in the capital goods and an environmental assessment of the impacts from the production of the capital goods as well as the impacts from the production of capital goods per tonne of waste collected per lifetime.

\subsection{Material consumption of capital goods for waste collection and transport}

The materials included in producing the capital goods are shown in Table 3.

HDPE is used for the body of the $0.24 \mathrm{~m}^{3}$ container. The total weight is $13 \mathrm{~kg}$. The wheels are made of rubber and attached to a steel axle. The body of the $1.1 \mathrm{~m}^{3}$ container is also HDPE but there is no steel 
axle. Instead it has four wheels consisting of a bandage of rubber and a rim of Polypropylene (PP) attached to a steel part. Smaller parts of Polyoxymethylene (POM) and Polyvinylchloride (PVC) are aggregated with the PP as "Other types of plastics" in the assessment. The total weight of the $1.1 \mathrm{~m}^{3}$ container is $50 \mathrm{~kg}$.

The cube consists of HDPE and steel. The total weight is $65.4 \mathrm{~kg}$. There are some small parts of rubber and plastics but it has not been possible to get data about these parts and they are not included in the assessment. Some years ago and still in some countries these cubes were made of reinforced glass fibre. Today there are higher demands for a good working environment during production of the cubes and therefore it is easier and cheaper for the container producers to produce these cubes from HDPE (Wulff, 2010).

The $19 \mathrm{~m}^{3}$ steel container consists of steel and is painted with powder paint. The total weight is 2209 $\mathrm{kg}$.

The truck consists of many different materials; the total weight of the empty truck is $11566 \mathrm{~kg}$. The main materials used are steel and iron for the body and the chassis corresponding to $87 \%$ of the total weight.

Intervals for the amounts of material used for producing the goods per tonnes of waste collected per lifetime are shown in Figure 2. The intervals are governed primarily by the uncertainties about the amount of waste collected during the lifetime of the capital goods (Table 2). The steel container has the highest amount of kg materials per tonne of waste collected since it may contain low-density G\&Y waste during the whole lifetime. C\&D waste gives the lowest value of $\mathrm{kg} /$ tonne waste collected by the steel container. In real life a container may be used for a variety of waste types. The containers produced of HDPE have a lower amount of material used depending on the size and thereby capacity. The large container uses less material per tonne of waste. The truck has the biggest capacity of collection per lifetime and needs $0.36-0.56 \mathrm{~kg}$ materials per tonne collected.

Table 3: Materials needed for production of capital goods used in waste collection and transport.

\begin{tabular}{|c|c|c|c|c|c|}
\hline & $\begin{array}{l}\text { 2-wheeler con- } \\
\text { tainer } 0.24 \mathrm{~m}^{3}\end{array}$ & $\begin{array}{l}\text { 4-wheeler con- } \\
\text { tainer } 1.1 \mathrm{~m}^{3}\end{array}$ & $\begin{array}{l}\text { Cube } \\
1.5 \mathrm{~m}^{3} \\
\end{array}$ & $\begin{array}{c}\text { Steel container } \\
19 \mathrm{~m}^{3} \\
\end{array}$ & $\begin{array}{c}\text { Collection } \\
\text { truck } 16 \mathrm{~m}^{3}\end{array}$ \\
\hline Materials & kg & kg & kg & kg & kg \\
\hline Total weight & 13 & 50 & 65.4 & 2209 & 11566 \\
\hline High density polyethylene & 10.6 & 37.6 & 40 & - & 419 \\
\hline Batch/colour/paint & 0.105 & 0.38 & 0.4 & 9.25 & 13 \\
\hline Other plastic types & - & 0.742 & - & - & - \\
\hline Rubber & 1.92 & 4.64 & - & - & 459 \\
\hline Steel & 0.624 & 6.38 & 25 & 2200 & 7370 \\
\hline Stainless steel & - & - & - & - & 15 \\
\hline Iron & - & - & - & - & 2674 \\
\hline Aluminium & - & - & - & - & 201 \\
\hline Lead (battery) & - & - & - & - & 95 \\
\hline Copper & - & - & - & - & 14 \\
\hline Brass & - & - & - & - & 9 \\
\hline Glass & - & - & - & - & 60 \\
\hline Textile & - & - & - & - & 57 \\
\hline Oil, grease & - & - & - & - & 62 \\
\hline Electronics & - & - & - & - & 56 \\
\hline Sulphuric acid (Battery) & - & - & - & - & 36 \\
\hline Bitumen & - & - & - & - & 6 \\
\hline Wood & - & - & - & - & 11 \\
\hline Cooling agent (R134a) & - & - & - & - & 1 \\
\hline Glycol & - & & - & - & 17 \\
\hline Ethanol & - & - & - & - & 4 \\
\hline
\end{tabular}




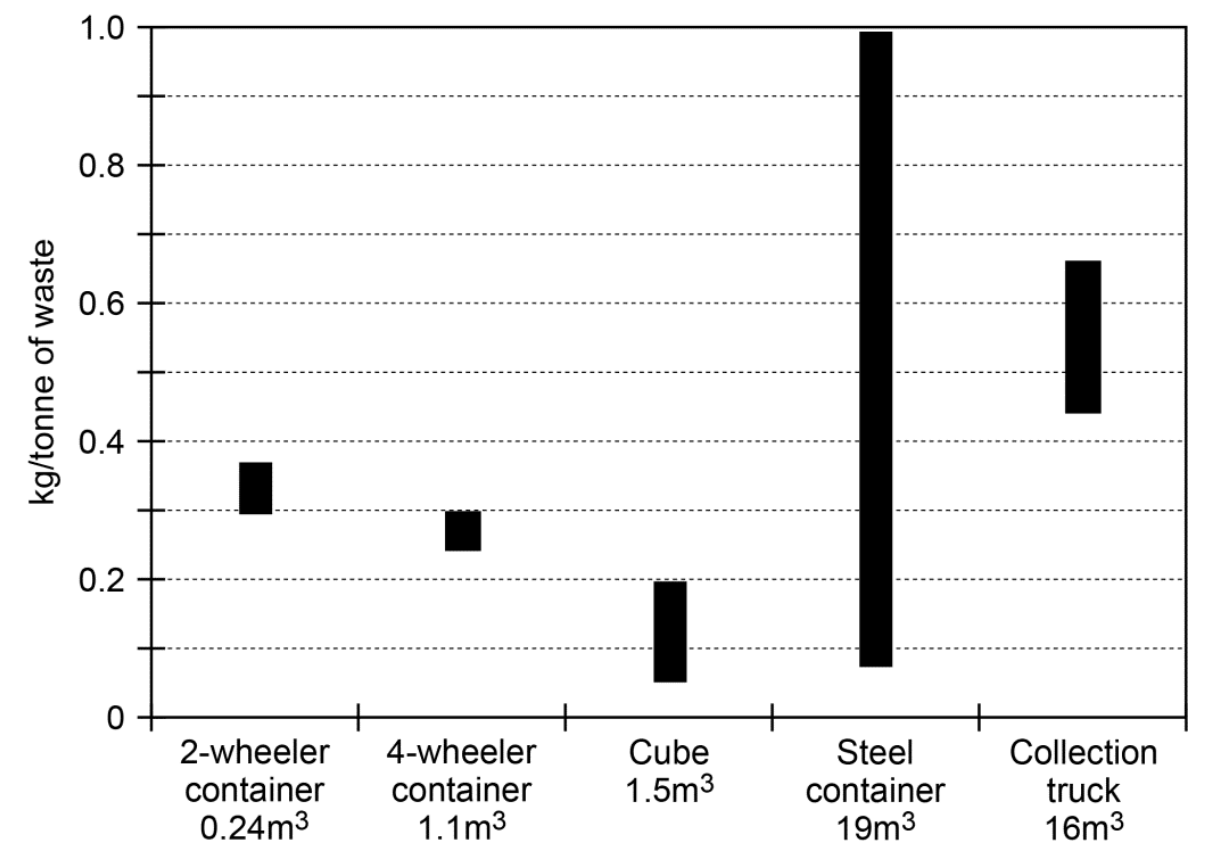

Figure 2: The amount of materials needed for producing capital goods per tonnes of waste collected by the specific good during its lifetime.

\subsection{Environmental impact assessment of capital goods for waste collection and transport}

The main impacts from the production of the capital goods for waste collection and transport are shown in Table 4. Some impact categories were less important and are left out. These are the impacts on Ozone Depletion, Terrestrial Eutrophication and Aquatic Eutrophication in relation to the emission of nitrogen.

Table 4: Life cycle impacts in milli-person equivalents for production of capital goods used in waste collection and transport.

\begin{tabular}{|c|c|c|c|c|c|c|}
\hline & $\begin{array}{c}\text { 2-wheeler } \\
\text { container } \\
0.24 \mathrm{~m}^{3} \\
\end{array}$ & $\begin{array}{c}\text { 4-wheeler } \\
\text { container } \\
1.1 \mathrm{~m}^{3} \\
\end{array}$ & $\begin{array}{l}\text { Cube } \\
1.5 \mathrm{~m}^{3} \\
\end{array}$ & $\begin{array}{c}\text { Steel container } \\
19 \mathrm{~m}^{3} \\
\end{array}$ & $\begin{array}{c}\text { Collection } \\
\text { truck } 16 \mathbf{m}^{3}\end{array}$ & $\begin{array}{c}\text { Collection } \\
\text { truck 21m3 } \\
\end{array}$ \\
\hline Impact category & mPE & mPE & mPE & mPE & mPE & mPE \\
\hline Global warming & 5.1 & 18.9 & 26.5 & 519 & 10251 & 10804 \\
\hline Ozone depletion & 0.8 & 2.1 & 0.5 & 16 & 652 & 659 \\
\hline Ozone formation (Vegetation) & 5.6 & 19.2 & 20.9 & 296 & 6188 & 6600 \\
\hline Ozone formation (Human) & 8.6 & 29.6 & 31.6 & 441 & 9155 & 9775 \\
\hline Acidification & 6.2 & 22.5 & 36.5 & 626 & 14911 & 15625 \\
\hline Terrestrial eutrophication & 2.0 & 6.2 & 8.1 & 149 & 3014 & 3195 \\
\hline Aquatic eutrophication EP(N) & 1.3 & 4.6 & 6.6 & 143 & 2752 & 2894 \\
\hline Aquatic eutrophication EP(P) & 25 & 129 & 379 & 7584 & 199988 & 208000 \\
\hline Resources (all) & 4.0 & 25 & 74 & 4245 & 104422 & 125723 \\
\hline Human toxicity, cancer & 55 & 272 & 657 & 32800 & 587000 & 629000 \\
\hline Human toxicity, non-cancer & 5 & 24 & 72 & 1550 & 34300 & 35900 \\
\hline Ecotoxicity & 10 & 45 & 90 & 2670 & 49000 & 52200 \\
\hline
\end{tabular}




\section{Global warming}

The impact on Global Warming from the production of the 2- and 4-wheeler containers was mainly caused by the production of HDPE and the transportation of materials for its production. From the production of the cube the main impact on Global Warming was also from the production of HDPE but also the metal contributed. The main material in the steel container is steel and the metalwork and beneficiation of iron ore gave the highest contribution to Global Warming. For the collection truck the steel production and the energy use gave the highest impacts on Global warming.

\section{Ozone Formation (impact on vegetation and humans) and Acidification}

For the impact categories: Ozone Formation (impact on vegetation and humans) and Acidification the impacts were caused by the same processes. The production of HDPE gave the main contribution to the impact on Ozone Formation and Acidification for the three HDPE containers. For the 2-wheeler the rubber production also gave a significant contribution whereas the 4-wheeler had a large contribution from transportation of materials. The cube had a contribution from the metal work to the impact on Ozone Formation and Acidification. The metalwork and beneficiation of iron ore gave the highest contribution to these impact categories for the steel container. As for the Global Warming the steel production and the energy production gave the highest impacts from the production of the collection truck.

\section{Aquatic Eutrophication (P-equivalents)}

An average European energy production mix was chosen for all goods assessed and results in impacts on aquatic eutrophication from the energy production from lignite for all goods. For the HDPE goods the metal work also contribute to the total impact in this category. For the steel container it is primarily the metal work and beneficiation of iron ore that contributes to the total impact. Beside the impacts from the energy production from lignite, steel processing is the main contributor to Aquatic Eutrophication for the production of the collection truck.

\section{Resource Depletion}

Metals are giving the main impacts for the assessed goods. Nickel, chromium, manganese and iron are the main contributors for the steel container and the truck. For the 2- and 4-wheeler, nickel and crude oil are the resources giving the highest impact on Resource Depletion.

For the cube the steel part gave a higher impact than the HDPE even though it is only a small part of the total mass. The use of the metals nickel, molybdenum, chromium and copper gave high contribution to the total impact on the Resource Depletion from the cube.

\section{Human Toxicity (Cancer/Non cancer)}

The metal working gave high impacts on Human Toxicity for all goods, even for the goods with only small amounts of steel compared to the total mass of the good. The ethylene production also gave impacts on this category for the HDPE goods.

\section{Ecotoxicity}

The HDPE production and the transportation of materials gave the main contributions to Ecotoxicity for the HDPE goods. For the steel container, the steel gave the highest contribution to this impact category and the highest contribution for the truck is the use of textile, rubber, electronics and steel. 


\section{Impacts per tonne of waste}

The impacts per tonne of waste collected are shown in Table 5. For the reason of simplicity, one single value is presented ( $\mathrm{mPE} /$ tonne of waste) for each good instead of an interval. The average amount of waste collected per lifetime was used to calculate the results shown in Table 5.

For the HDPE containers the impacts decreased with the volume of the container and the amount of waste collected. For most of the impact categories the lowest impact was observed in cases with larger amounts of waste collected. The production of steel gives other types of impacts and the impacts here are still higher for the steel container than for the HDPE containers even though more waste is collected. Comparing the impacts per tonne of waste for the containers shows that one type is not contributing more than the others and that it depends on the impact category. Rives et al. (2010) also found that the HDPE containers contribute more to e.g. Global Warming than the steel containers whereas the steel containers contribute more to the eutrophication potential.

The truck has the highest impacts due to the complexity of the materials used although it collects the biggest amount of waste compared to the containers.

This assessment includes only the production of the goods and does not consider the whole lifetime of the products and thus exclude the disposal including recycling, landfilling or incineration. The impacts from the products would probably be lower if the disposal phase was included since materials and resources would likely be recycled and substitute for the production of materials based on virgin resources.

Table 5: Life cycle impacts in milli-person equivalents per tonne of waste collected during the lifetime of the capital goods used for waste collection and transport. The results for the toxic categories are presented in Comparative Toxic Units (CTU) also per tonne of waste. The tonnes of waste are an average of the numbers presented in Table 2.

\begin{tabular}{|c|c|c|c|c|c|c|c|}
\hline & $\begin{array}{l}\text { 2-wheeler } \\
\text { container } \\
0.24 \mathbf{m}^{3}\end{array}$ & $\begin{array}{l}\text { 4-wheeler } \\
\text { container } \\
1.1 \mathrm{~m}^{3}\end{array}$ & $\begin{array}{l}\text { Cube } \\
1.5 \mathrm{~m}^{3}\end{array}$ & $\begin{array}{l}\text { Steel } \\
\text { container } \\
(G \& Y) \\
19 m^{3}\end{array}$ & $\begin{array}{l}\text { Steel } \\
\text { container } \\
(C \& D) 19 \mathrm{~m}^{3}\end{array}$ & $\begin{array}{l}\text { Collection } \\
\text { truck } 16 \mathbf{m}^{3}\end{array}$ & $\begin{array}{l}\text { Collection } \\
\text { truck } 21 \mathbf{m}^{3}\end{array}$ \\
\hline Impact category & $\begin{array}{r}\text { mPE/tonne } \\
\text { of waste }\end{array}$ & $\begin{array}{c}\text { mPE/tonn } \\
\text { e of waste }\end{array}$ & $\begin{array}{r}\mathrm{mPE} / \mathrm{ton} \\
\text { ne of } \\
\text { waste } \\
\end{array}$ & $\begin{array}{c}\mathrm{mPE} / \text { tonn } \\
\text { e of waste }\end{array}$ & $\begin{array}{r}\text { mPE/tonne of } \\
\text { waste }\end{array}$ & $\begin{array}{r}\mathrm{mPE} / \text { tonne } \\
\text { of waste }\end{array}$ & $\begin{array}{r}\text { mPE/tonne } \\
\text { of waste }\end{array}$ \\
\hline Global warming & 0.13 & 0.10 & 0.05 & 0.18 & 0.02 & 0.49 & 0.39 \\
\hline Ozone depletion & 0.02 & 0.01 & 0.00 & 0.01 & 0.00 & 0.03 & 0.02 \\
\hline $\begin{array}{l}\text { Ozone formation } \\
\text { (Vegetation) }\end{array}$ & 0.14 & 0.10 & 0.04 & 0.10 & 0.01 & 0.29 & 0.24 \\
\hline $\begin{array}{l}\text { Ozone formation } \\
\text { (Human) }\end{array}$ & 0.22 & 0.16 & 0.06 & 0.15 & 0.02 & 0.43 & 0.35 \\
\hline Acidification & 0.16 & 0.12 & 0.07 & 0.21 & 0.02 & 0.71 & 0.57 \\
\hline $\begin{array}{l}\text { Terrestrial Eutrophi- } \\
\text { cation }\end{array}$ & 0.05 & 0.03 & 0.02 & 0.05 & 0.01 & 0.14 & 0.12 \\
\hline $\begin{array}{l}\text { Aquatic Eutrophica- } \\
\text { tion EP(N) }\end{array}$ & 0.03 & 0.02 & 0.01 & 0.05 & 0.01 & 0.13 & 0.10 \\
\hline $\begin{array}{l}\text { Aquatic Eutrophica- } \\
\text { tion EP(P) }\end{array}$ & 0.61 & 0.70 & 0.73 & 2.56 & 0.30 & 9.50 & 7.53 \\
\hline Resources (all) & 0.10 & 0.14 & 0.14 & 1.43 & 0.17 & 4.96 & 4.55 \\
\hline $\begin{array}{l}\text { Human toxicity, can- } \\
\text { cer }\end{array}$ & 1.38 & 1.48 & 1.26 & 11.07 & 1.29 & 27.89 & 22.77 \\
\hline $\begin{array}{l}\text { Human toxicity, non- } \\
\text { cancer }\end{array}$ & 0.14 & 0.13 & 0.14 & 0.52 & 0.06 & 1.63 & 1.30 \\
\hline Ecotoxicity & 0.26 & 0.24 & 0.17 & 0.90 & 0.11 & 2.33 & 1.89 \\
\hline
\end{tabular}




\section{Truck with three axles}

A bigger collection truck with three axles ( 26 tonnes and $21 \mathrm{~m}^{3}$ body) requires according to the manufacturer, an additional $1300 \mathrm{~kg}$ steel for the body of the truck and an additional $400 \mathrm{~kg}$ steel for the chassis compared to the 2 -axle truck ( 18 tonnes and $16 \mathrm{~m}^{3}$ body). The impacts on the non-toxic categories were increased with up to $6.7 \%$ by this change of the materials used for the truck. The impact on the toxic impact categories increased with up to $7 \%$ and the impact on Resource Depletion increased by $20 \%$ (see Table 4 and Table 5 ). This is a rough estimate since many materials are excluded, e.g. rubber for the extra tires. However, it suggests that a larger truck causes more impacts from the production of capital goods, but less per tonne of waste collected during the lifetime. The 3-axle truck can collect around twice as much waste as the 2-axle truck. Although the 2-axles truck can compact the waste more, the restriction on the load on the axles limits its capacity (Dennis Eagle, 2010).

\section{System - container, truck, and transportation}

In order to assess the importance of capital goods compared to the fuel consumption for waste collection and transport, a collection system was modelled involving a $0.24 \mathrm{~m}^{3}$ HDPE container, an 18 tonnes 2-axle truck using 8.7 litre of diesel for collection of 1 tonne of waste (Larsen et al., 2009) and transporting 1 tonne of waste $25 \mathrm{~km}$ to the treatment facility. The results are shown in Figure 3 . The impacts from the capital goods dominate $(>85 \%$ of total impact) within the categories HumanToxicity (non cancer and cancer), Ecotoxicity, Resource Depletion and Aquatic Eutrophication, but are also important in the other categories ( $>13 \%$ of the total impact). The reason for the high impact on Aquatic Eutrophication is the use of lignite for energy production in the steel industry. This will depend on the location of the production site of the truck and since this is not specified a European average energy mix was used. Also the impacts on the toxic categories were mainly caused by the truck namely the production of steel.

It was found that the importance of the capital goods decreases with increasing distance of transportation but also that a long distance is needed before the impacts from capital goods contributes less than $10 \%$ of the total impacts. For the impact categories: Ozone depletion, Aquatic eutrophication (Pequivalents), Resources depletion, Human toxicity and Ecotoxicity the transportation distances have to exceed $300 \mathrm{~km}$ before the impact of the capital goods constitutes less than $10 \%$ of the total impact.

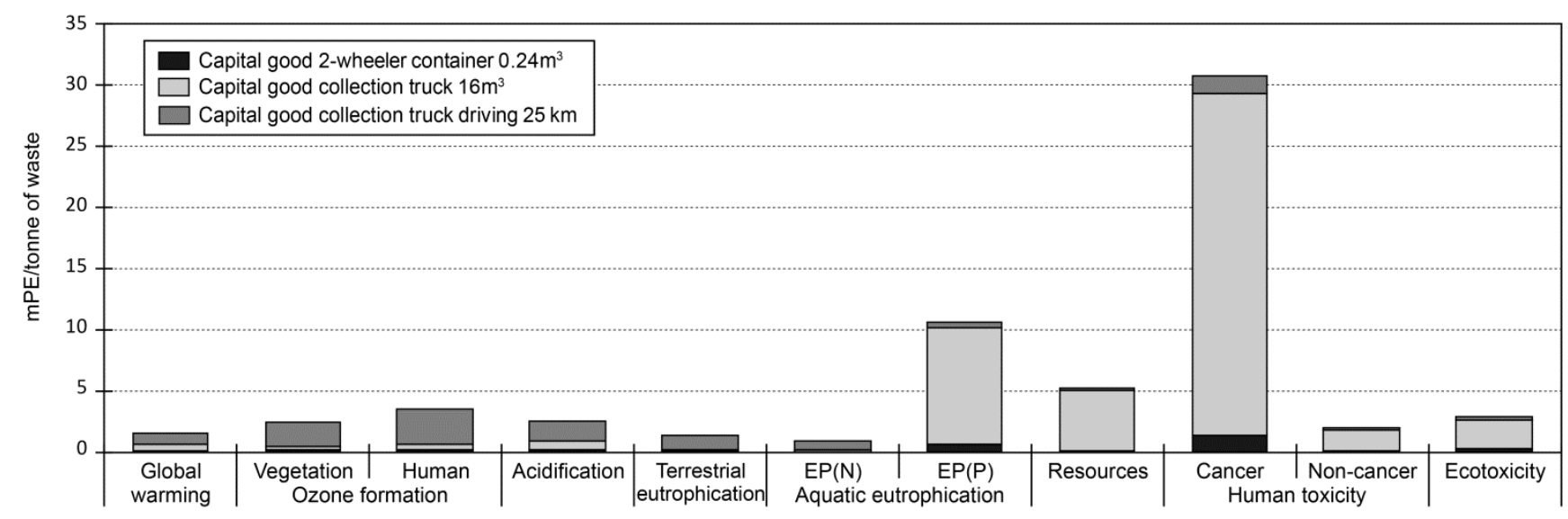

Figure 3: Contribution to impact categories from container, truck and the transportation of waste for $25 \mathrm{~km}$. All presented per tonne of waste.

\section{Conclusion}


The materials for producing three different types of HDPE containers $\left(0.24 \mathrm{~m}^{3}, 1.1 \mathrm{~m}^{3}\right.$ and $1.5 \mathrm{~m}^{3}$ cube $)$ were quantified as well as the materials for producing a $19 \mathrm{~m}^{3}$ steel container and an 18 tonnes waste collection truck.

An assessment of the environmental impacts related to the production of the goods was performed. The main materials of the goods caused the highest impacts. Production of HDPE gave the highest impacts for the HDPE containers, the steel caused the highest impacts for the steel container and the steel production caused the main impacts for the truck. Also the transportation of materials to manufacturing plant turned out to be important for some impact categories e.g. Ecotoxicity.

The impacts of producing the waste bins increased with the foreseen amount of waste collected, but per tonne of waste collected over a lifetime the impacts were in most cases smallest for the larger containers. The impact on Aquatic eutrophication (P-equivalents) and Resources depletion were higher for the 4-wheeler and the cube than for the 2-wheeler container because of the higher amount of steel used. The collection truck had the highest impact per tonne of waste collected. Overall the HDPE containers had a lower impact per tonne of waste in all impact categories.

The impact of producing the capital goods for waste collection and transport cannot be neglected since the capital goods dominate the categories Human-Toxicity (non cancer and cancer), Ecotoxicity, Resource Depletion and Aquatic Eutrophication, but also plays a role within the other impact categories when compared to the impacts from combustion of fuels for the collection and transport of the waste. In the example assessed, the transportation distance was $25 \mathrm{~km}$, and as the distance increases the importance of the capital goods decreases. But for many impact categories, the transportation distances have to exceed $300 \mathrm{~km}$ before the impact of the capital goods constitutes less than $10 \%$ of the total impact.

\section{Acknowledgement}

The authors would like to thank Udo Fröhlingsdorf from Environmental Systems Expertise (ESE) group for the help on the data collection for the 2- and 4-wheeler containers and Rikke Møller from Kingspan finding data on the cube.

The authors would like to thank the graduate school Residual Resource Research (3R) at the Technical University of Denmark for financing the scholarship for this PhD research.

\section{References}

EASEWASTE (2011) Environmental Assessment of Solid Waste Systems and Technologies. Technical University of Denmark, www.easewaste.dk.

ESE World B.V. Environmental Systems Expertise (2010) Horsterweg 18H, NL-6199 AC, Maastricht Airport, Netherlands.

Christensen, T. H. (2011) Solid Waste Technology \& Management. Volume 1 \& 2. (Ed T. H. Christensen), John Wiley \& Sons, Ltd, Chichester, United Kingdom.

Dennis Eagle (2010) Personal communication with Brian Olesen, Managing Director of Dennis Eagle vendor, Phoenix Denmark, Dalager 15, 2605 Brøndby, Denmark. 
Geesinknorba (2011) Rearloadere, RL200 and RL300, Norba group AB, S-384 21 Blomstermåla, Sweden, http://www.geesinknorba.com/.

Hauschild, M., Potting, J. (2005) Spatial differentiation in LCA impact assessment - The EDIP 2003 methodology. Environmental news No. 80 2005. Guideline from the Danish Environmental Protection Agency. Copenhagen, Denmark.

Jensen C. H. (2010) Personal communication with Regulation and Certification Manager Claus Henrik Jensen at Volvo Lastvogne Danmark A/S, Volvo Nordic, Denmark.

Kingspan Environmental (2011) Personal communication with Sales Manager Rikke Møller and Design Engineer John Lennon, Mørupvej 27-35, 7400 Herning, Denmark.

Larsen, A. W., Vrgoc, M., Christensen, T. H., and Lieberknecht, P. (2009) Diesel consumption in waste collection and transport and its environmental significance. Waste management research, 27(7), 652-659.

Laurent, A., Olsen, S. I., Hauschild M. Z. (2011a) Normalization in EDIP97 and EDIP2003: updated European inventory for 2004 and guidance towards a consistent use in practice. Int. J. Life cycle assess, 16:401-409.

Laurent A, Lautier A, Rosenbaum RK, Olsen SI, Hauschild MZ (2011b) Normalization references for Europe and North America for application with USEtox ${ }^{\mathrm{TM}}$ characterization factors. Int J Life Cycle Assess 16(8).

Lyngsgaard (2011) Vorbassevej 21, DK-6622 Bække, Denmark, http://lyngsgaard.com/.

Fatta, D., Papadopoulos, A., Kourmoussis, F., Mentzis A., Sgourou E., Moustakas K., Loizidou M., Siouta N. (2004) Estimation methods for the generation of construction and demolition waste in Greece. Proceedings of the international conference organised by the Concrete and Masonry Research Group and held at Kingston University - London on 14-15 September 2004.

PRé, Product Ecology consultants (2011) Simapro software version 7.2, The Netherlands. www.presustainability.com/.

Rives, J., Rieradevall, J., Gabarrell, X. (2010) LCA comparison of container systems in municipal solid waste management. Waste Management 30, 949-957.

Stranddorf H. K., Hoffmann L., Schmidt A. (2005) Update on impact categories, normalisation and weighting in LCA-selected EDIP97 data. Environmental Project Nr. 995 2005. Danish Environmental Protection Agency, Copenhagen, Denmark.

Swiss Centre for Life Cycle Inventories (2011) Ecoinvent, V2.2, c/o Empa/Technology \& Society Lab (TSL), Lerchenfeldstrasse 5, 9014 St-Gallen, Switzerland.

USEtox (2009) USEtox model developed by the Task Force on Toxic Impacts under the UNEPSETAC Life Cycle Initiative. http://www.usetox.org/.

Volvo (2010) Volvo truck corporation, Environmental Product Declaration, Volvo FH12 and Volvo FM12, Euro3. Göteborg, Sweden, http://www.volvo.com/NR/rdonlyres/E8FD3F6B-B06B-4EBEBA7D-A529AFE0BFD0/0/euro3 03.pdf.

Wenzel, H., Hauschild, M. Z., Alting, L. (1997) Environmental Assessment of Products. Methodology, tools and case studies in product development, vol. 1. Chapman \& Hall, 2-6 Boundary row, London, United Kingdom. 
Wulff H. E. (2010) Personal communication with Director H.E. Wulff in container vendor H.E.W. A/S, Sunekær 6, 5471 Søndersø, Denmark. 